Keywords: $M C U, A R P, I S D P$

Retention: Permanent

\title{
Results of Routine Strip Effluent Hold Tank and Decontaminated Salt Solution Hold Tank Samples from Modular Caustic-Side Solvent Extraction Unit during Macrobatch 5 Operations
}

T. B. Peters

F. F. Fondeur

April 2013

Savannah River National Laboratory Savannah River Nuclear Solutions

Aiken, SC 29808

Prepared for the U.S. Department of Energy under

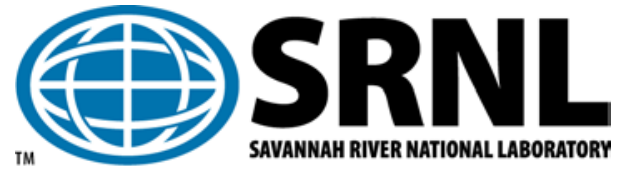
contract number DE-AC09-08SR22470. 
SRNL-STI-2013-00194

Revision 0

\section{DISCLAIMER}

This work was prepared under an agreement with and funded by the U.S. Government. Neither the U.S. Government or its employees, nor any of its contractors, subcontractors or their employees, makes any express or implied:

1. warranty or assumes any legal liability for the accuracy, completeness, or for the use or results of such use of any information, product, or process disclosed; or

2. representation that such use or results of such use would not infringe privately owned rights; or

3. endorsement or recommendation of any specifically identified commercial product, process, or service.

Any views and opinions of authors expressed in this work do not necessarily state or reflect those of the United States Government, or its contractors, or subcontractors.

\section{Printed in the United States of America}

Prepared for

U.S. Department of Energy 


\section{REVIEWS AND APPROVALS}

\section{AUTHORS:}

T. B. Peters, Author, SRNL/ACP

Date

F. F. Fondeur, Co-Author, SRNL/SASP

Date

TECHNICAL REVIEW:

C. A. Nash, Technical Reviewer, SRNL/ACP

Date

APPROVAL:

F. M. Pennebaker, SRNL/ACP, Manager

Date

S. L. Marra, SRNL/E\&CPT Research Programs, Manager

Date

D. J. Martin, Manager, H Tank Farm Engineering

Date 


\section{EXECUTIVE SUMMARY}

Strip Effluent Hold Tank (SEHT) and Decontaminated Salt Solution Hold Tank (DSSHT) samples from several of the "microbatches" of Integrated Salt Disposition Project (ISDP) Salt Batch ("Macrobatch") 5 have been analyzed for ${ }^{238} \mathrm{Pu},{ }^{90} \mathrm{Sr},{ }^{137} \mathrm{Cs}$, and by Inductively Coupled Plasma Emission Spectroscopy (ICPES). The results indicate good decontamination performance within process design expectations. While the data set is sparse, the results of this set and the previous set of results for Macrobatch 4 samples indicate generally consistent operations.

The DSSHT samples show continued presence of titanium, likely from leaching of the monosodium titanate in the Actinide Removal process (ARP). 


\title{
LIST OF ABBREVIATIONS
}

\author{
ARP - Actinide Removal Process \\ DSS - Decontaminated Salt Solution \\ DSSHT - Decontaminated Salt Solution Hold Tank \\ ICPES - inductively-coupled plasma emission spectroscopy \\ MCU - Modular Caustic-Side Solvent Extraction Unit \\ MST - monosodium titanate \\ SE - Strip Effluent \\ SEHT - Strip Effluent Hold Tank \\ SRNL - Savannah River National Laboratory \\ SSRT - Salt Solution Receipt Tank
}


SRNL-STI-2013-00194

Revision 0

\subsection{Introduction}

During operation of the ISDP, quantities of salt waste are processed through the Actinide Removal Process (ARP) and MCU in batches of $~ 3800$ gallons. Monosodium titanate (MST) is used in ARP to adsorb actinides and strontium from the salt waste and the waste slurry is then filtered prior to sending the clarified salt solution to MCU. The MCU uses solvent extraction technology to extract cesium from salt waste and concentrate cesium in an acidic aqueous stream (Strip Effluent - SE), leaving a decontaminated caustic salt aqueous stream (Decontaminated Salt Solution - DSS). Sampling occurs in the Decontaminated Salt Solution Hold Tank (DSSHT) and Strip Effluent Hold Tank (SEHT) in the MCU process. The MCU sample plan ${ }^{1}$ requires that batches be sampled and analyzed for plutonium and strontium content by Savannah River National Lab (SRNL) to determine MST effectiveness. The cesium measurement is used to monitor cesium removal effectiveness and the inductively coupled plasma emission spectroscopy (ICPES) is used to monitor inorganic carryover.

A previous report provided the results of several sets of sample results from Macrobatch 4 operations. $^{2}$ Since that report, SRNL received subsequent SEHT and DSSHT samples from Macrobatch 5 (9/2012 to 1/2013).

\subsection{Experimental Procedure}

The samples were contained in 10-mL P-nut vials. SEHT samples were delivered in doorstops for shielding purposes, while the DSSHT samples were delivered in thief holders. Samples were removed from the holders and sent to Analytical Development. The DSSHT samples were not diluted or filtered. SEHT samples were diluted where necessary to reduce personnel exposure. Any dilutions were accounted for in the reported results.

All of the work was reviewed by a technical design check that follows E7, 2.60. This type of QA program typically consists of review and assessment of the following parameters such as correct input selection, correct use of analytical methods, and general approach to the data analysis.

The design check is required by SRNL and is documented and retained.

\subsection{Results and Discussion}

The radiochemical results from the DSSHT and SEHT analyses are listed in Table 1. Entries in the "Source Material" column are calculated from knowing the concentrations and blend volumes. ${ }^{3,4}$ 
Table 1. Radiochemical Results for the DSSHT and SEHT Results

\begin{tabular}{|c|c|c|c|c|}
\hline Sample ID & Sample Date & ${ }^{\mathbf{2 3 8}} \mathbf{P u}(\mathbf{d p m} / \mathbf{m L})$ & ${ }^{\mathbf{9 0}}$ Sr (dpm/mL) & $\left.{ }^{\mathbf{1 3 7}} \mathbf{C s} \mathbf{( d p m} / \mathbf{m L}\right)$ \\
\hline \multicolumn{5}{|c|}{ DSSHT Samples } \\
\hline MCU-12-301 & $9 / 4 / 2012$ & $4.24 \mathrm{E}+02(4.74 \%)$ & $3.85 \mathrm{E}+03(14.8 \%)$ & $1.01 \mathrm{E}+06(5.00 \%)$ \\
\hline MCU-12-357 & $9 / 20 / 2012$ & $5.63 \mathrm{E}+02(5.07 \%)$ & $4.66 \mathrm{E}+03(15.0 \%)$ & $4.71 \mathrm{E}+05(5.00 \%)$ \\
\hline MCU-12-409 & $10 / 1 / 2012$ & $7.25 \mathrm{E}+02(5.14 \%)$ & $1.67 \mathrm{E}+03(9.82 \%)$ & $4.79 \mathrm{E}+05(5.00 \%)$ \\
\hline MCU-12-497 & $11 / 5 / 2012$ & $7.13 \mathrm{E}+02(6.44 \%)$ & $1.74 \mathrm{E}+03(8.38 \%)$ & $2.80 \mathrm{E}+05(5.00 \%)$ \\
\hline MCU-12-538 & $11 / 26 / 2012$ & $1.38 \mathrm{E}+03(7.72 \%)$ & $1.86 \mathrm{E}+03(13.0 \%)$ & $4.69 \mathrm{E}+05(5.00 \%)$ \\
\hline MCU-13-04 & $1 / 4 / 2013$ & $1.87 \mathrm{E}+03(6.59 \%)$ & $3.74 \mathrm{E}+03(13.9 \%)$ & $6.50 \mathrm{E}+05(5.00 \%)$ \\
\hline \multicolumn{5}{|c|}{ SEHT Samples } \\
\hline MCU-12-305 & $9 / 4 / 2012$ & $3.24 \mathrm{E}+01(15.5 \%)$ & $<1.32 \mathrm{E}+02$ & $1.41 \mathrm{E}+08(5.00 \%)$ \\
\hline MCU-12-408 & $10 / 1 / 2012$ & $1.74 \mathrm{E}+01(21.8 \%)$ & $<1.60 \mathrm{E}+03$ & $1.59 \mathrm{E}+09(5.00 \%)$ \\
\hline MCU-12-501 & $11 / 12 / 2012$ & $<2.16 \mathrm{E}+01$ & $4.68 \mathrm{E}+03(13.6 \%)$ & $1.43 \mathrm{E}+09(5.00 \%)$ \\
\hline MCU-12-539 & $11 / 26 / 2012$ & $<1.37 \mathrm{E}+01$ & $<2.33 \mathrm{E}+02$ & $1.62 \mathrm{E}+09(5.00 \%)$ \\
\hline MCU-13-08 & $1 / 4 / 2013$ & $3.29 \mathrm{E}+02(8.08 \%)$ & $1.33 \mathrm{E}+04(12.8 \%)$ & $1.86 \mathrm{E}+09(5.00 \%)$ \\
\hline \multicolumn{7}{|c|}{$3.06 \mathrm{E}+04$} & $4.18 \mathrm{E}+05$ & $1.28 \mathrm{E}+08$ \\
\hline
\end{tabular}

The apparent low ${ }^{137} \mathrm{Cs}$ value for the first SE sample, and high value for the first DS sample and likely not indications of process upsets, but rather conditions that result from this being a sample very early in the macrobatch. Heels from the previous macrobatch, or cleaning residues can affect the sample results early in each macrobatch. For example, the last ${ }^{137} \mathrm{Cs}$ result from Macrobatch 4 was $1.06 \mathrm{E}+04 \mathrm{dpm} / \mathrm{mL}$. If this heel was retained in the system until the startup of Macrobatch 5, this can cause the first samples to be relatively high. 
While we do not have many data points for this Macrobatch, what we do have shows a similar pattern to the overall behavior from Macrobatch 4 operations. Table 2 lists the average DF values for ${ }^{238} \mathrm{Pu},{ }^{90} \mathrm{Sr}$ and ${ }^{137} \mathrm{Cs}$ for both Macrobatch 4 and 5. ${ }^{\Pi}$ The values in parentheses are the \% relative standard deviation.

Table 2. Average DF Values from Macrobatch 4 and 5

\begin{tabular}{|c|c|c|}
\hline Isotope & Average Macrobatch 4 DF & Average Macrobatch 5 DF \\
\hline${ }^{238} \mathrm{Pu}$ & $29.6(73.7 \%)$ & $35.6(44.4 \%)$ \\
\hline${ }^{90} \mathrm{Sr}$ & $133(33.3 \%)$ & $184(41.7 \%)$ \\
\hline${ }^{137} \mathrm{Cs}$ & $139(63.6 \%)$ & $289(33.1 \%)$ \\
\hline
\end{tabular}

The purpose in comparing the two macrobatches is to establish that the average decontamination of these three isotopes is approximately the same. Given the differences in the feed and in operating conditions, some variation in the DF values is expected. For example, the difference in the DF values for ${ }^{137}$ Cs should not be taken as Macrobatch 5 necessarily being much more efficient in cesium removal. The high \%RSD also makes it problematic to make direct comparisons.

Figure 1 shows the graph of the ${ }^{238} \mathrm{Pu}$ results in the DSSHT for all of the Macrobatch 5 DSSHT samples. Figure 2 shows the same for ${ }^{90} \mathrm{Sr}$. Figure 3 shows the similar ${ }^{137} \mathrm{Cs}$ data, but also includes the SEHT sample results.

Figure 1. ${ }^{238}$ Pu Data for Macrobatch 5 DSSHT Samples

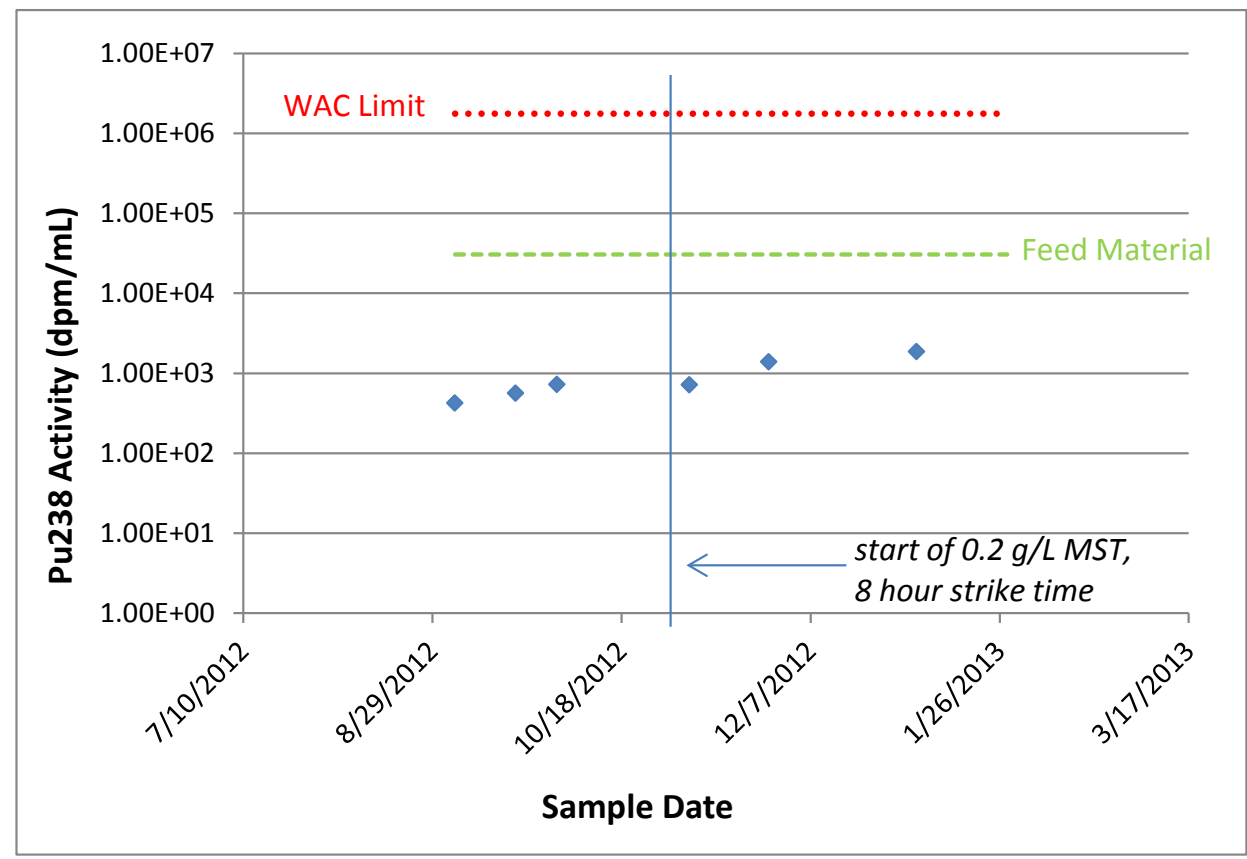

${ }^{\Pi}$ Recall that DF is defined as the feed value divided by the DSSHT sample value. 
While the graph of the Pu data can show the overall trend, it is also important to consider the flow rates as recorded in the facility, as well as the periodicity of the removal of the MST filter cake. At 11/03/2012, the ARP facility switched from using $0.4 \mathrm{~g} / \mathrm{L}$ of MST to $0.2 \mathrm{~g} / \mathrm{L}$ of MST, as well as switching from a 12 hour strike time to an 8 hour strike time. The reduction in MST and the strike time will undoubtedly decrease the overall removal of $\mathrm{Pu}$ and $\mathrm{Sr}$, and this may be represented in the increase in the activity in the DSSHT samples for the last two sample results.

\section{Figure 2. ${ }^{90}$ Sr Data for Macrobatch 5 DSSHT Samples}

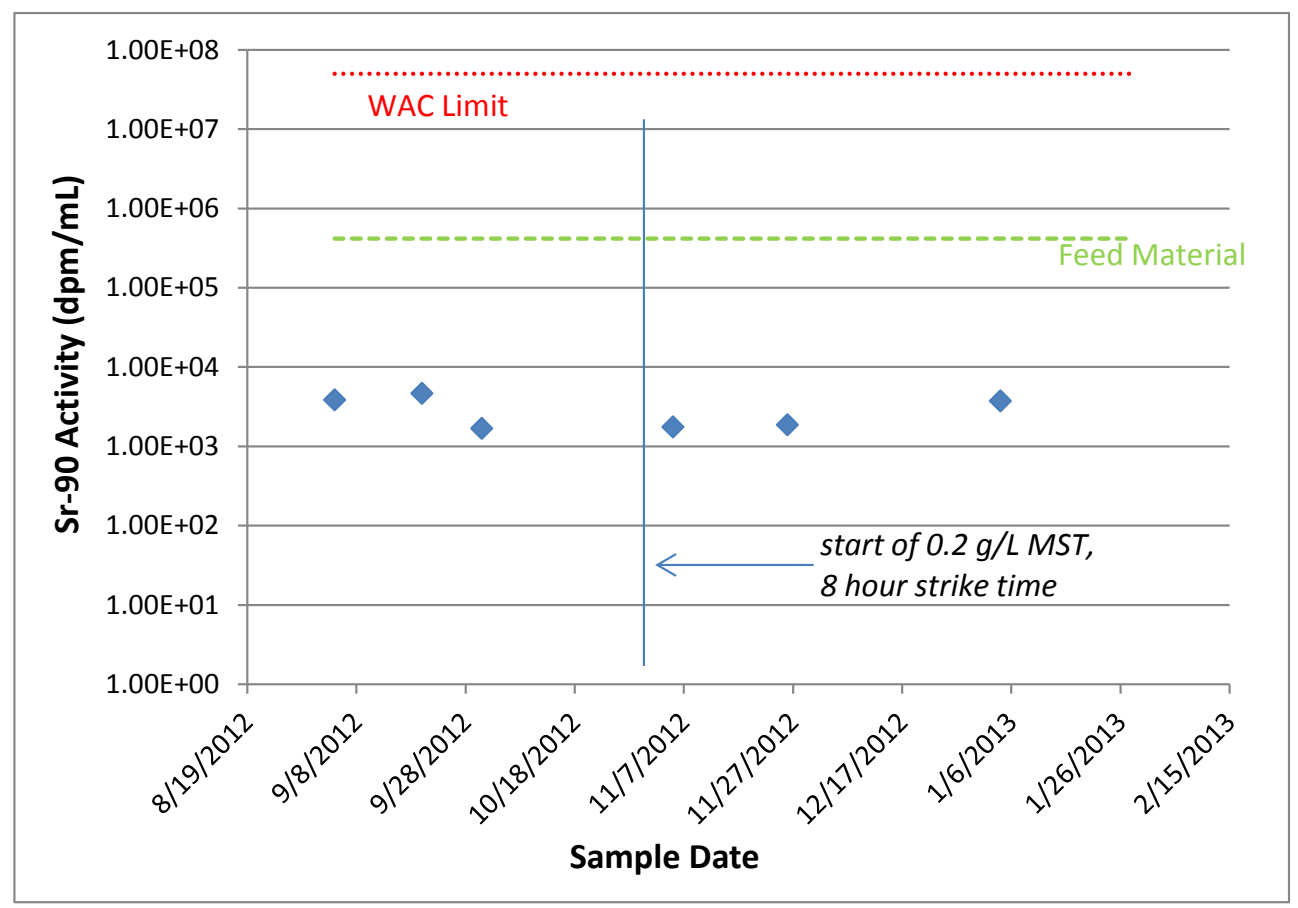

For the ${ }^{137}$ Cs results, both the DSSHT and SEHT results are shown. See Figure 3. The DSSHT samples are all well below the WAC limit, and the SEHT samples give an average concentration factor of $13.3\left(11.0 \%\right.$ RSD). ${ }^{\nabla}$ See Figure 4.

\footnotetext{
$\nabla$ The concentration factor (CF) is defined as the SEHT value divided by the feed value. In this particular case, the first sample result is excluded for the purposes of the calculation.
} 
Figure 3. ${ }^{137}$ Cs Data for Macrobatch 5 DSSHT and SEHT Samples

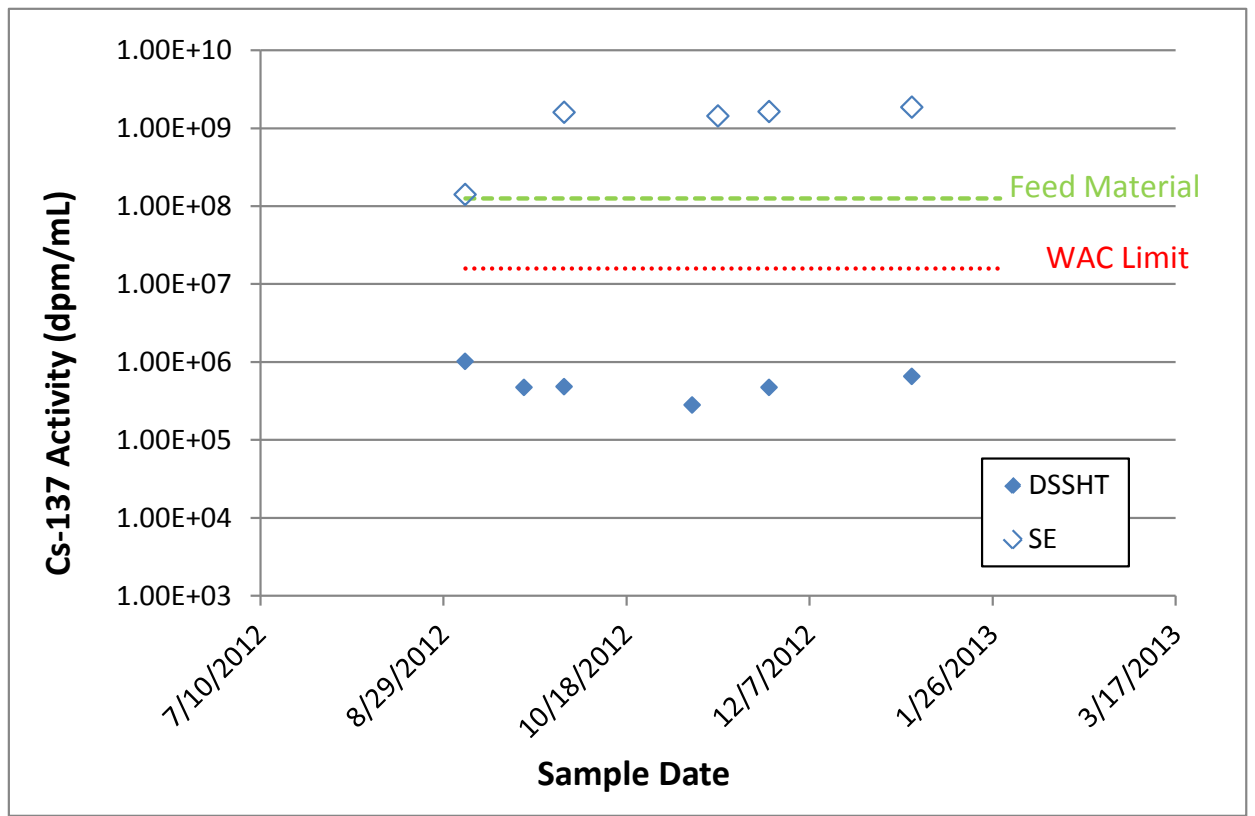

Figure 4. Concentration Factor For Macrobatch 5 Samples

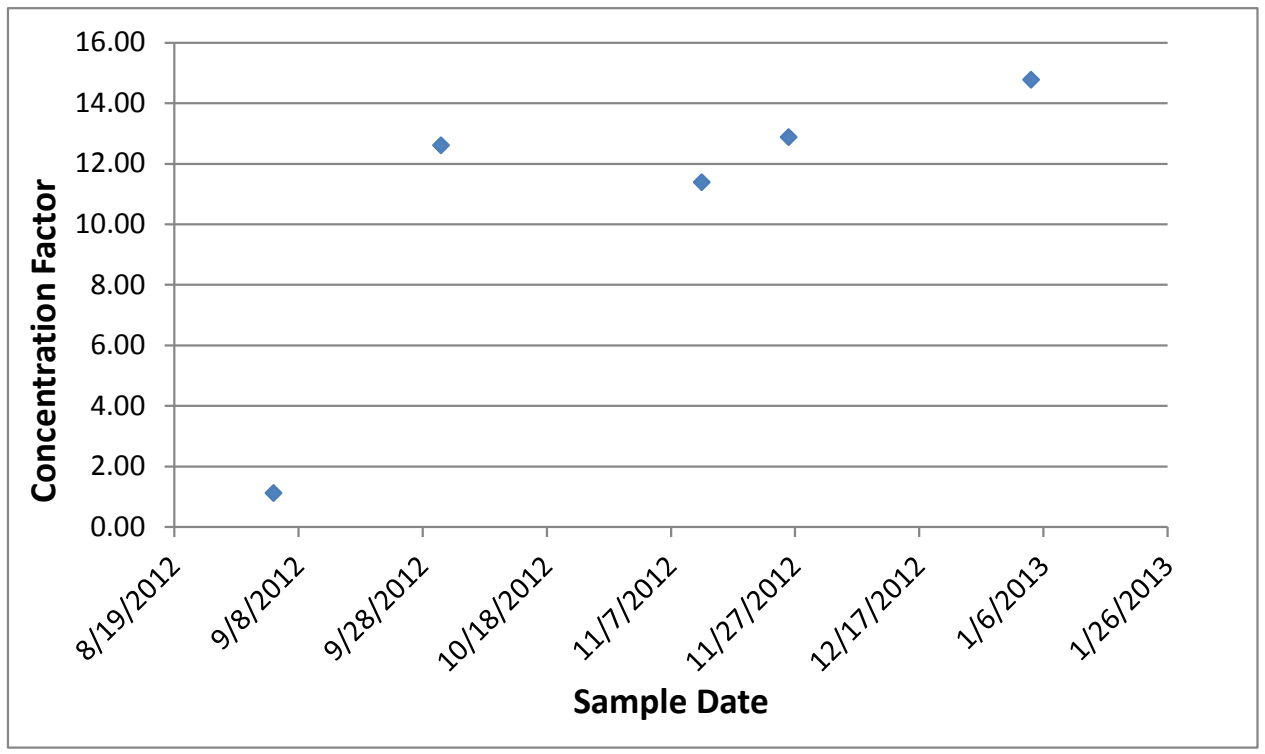


During the sample period, F/H Laboratory was analyzing DSSHT and SEHT samples for ${ }^{137}$ Cs content. Figure 5 shows the comparison of results between SRNL and F/H Lab.

\section{Figure 5. Comparison of SRNL and F/H Lab ${ }^{137}$ Cs Sample Results}

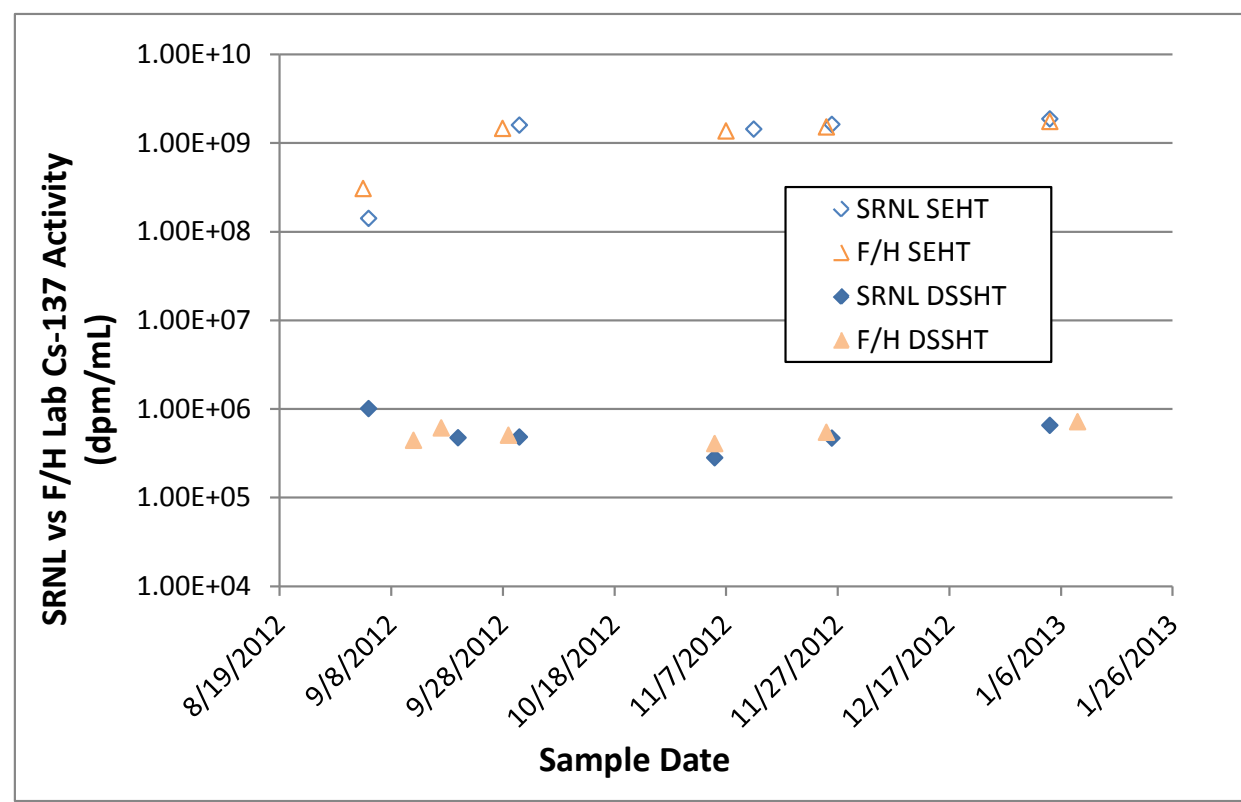

As an entire data set, the SRNL and F/H results are statistically similar from each other.

The ICPES results for the DSSHT samples are listed in Table 3, and the ICPES results for the SEHT samples are listed in Table 4. Note that material from Tank 49H undergoes a $\sim 20 \mathrm{vol} \%$ dilution from ARP and MCU. ${ }^{\Upsilon}$ Therefore, direct comparisons between the source material and the DSSHT sample results should take this into account. We note that a comparison of several of the more concentrated analytes (Al, B, Cr, K, Na, $\mathrm{P}$, and S) gives an average dilution factor of $\sim 22 \%$, indicating that additional sources of dilution have largely been avoided.

\footnotetext{
${ }^{\Upsilon}$ Each 3600 gallon batch of material is mixed with 210 gallons of MST slurry, and is then combined with 1 volume of scrub acid for each 7.5 volumes of salt solution (this is double the nominal rate of scrub acid). This dilutes each 3600 gallons to 4318 gallons, or $20 \mathrm{vol} \%$ increase in volume.
} 
Table 3. ICPES Results for the DSSHT Samples (mg/L)

\begin{tabular}{|c|c|c|c|c|c|c|c|}
\hline Analyte & $\begin{array}{c}\text { MCU- } \\
12-301\end{array}$ & $\begin{array}{c}\text { MCU- } \\
12-357\end{array}$ & $\begin{array}{c}\text { MCU- } \\
12-409\end{array}$ & $\begin{array}{c}\text { MCU- } \\
12-497\end{array}$ & $\begin{array}{c}\text { MCU- } \\
12-538\end{array}$ & $\begin{array}{c}\text { MCU- } \\
13-04\end{array}$ & Source \\
\hline $\mathrm{Al}$ & 2150 & 3920 & 4750 & 3870 & 4680 & 4790 & 5856 \\
\hline $\mathrm{B}$ & 42.4 & 48.7 & 48.9 & 35.2 & 47.0 & 49.7 & 49.5 \\
\hline $\mathrm{Ba}$ & 1.02 & 0.89 & 0.49 & $<0.62$ & $<0.62$ & 0.63 & $<0.52$ \\
\hline $\mathrm{Ca}$ & 1.6 & $<1.49$ & $<1.49$ & 0.87 & 1.08 & 0.99 & $<0.63$ \\
\hline $\mathrm{Cr}$ & 29.3 & 37.0 & 39.5 & 32.0 & 39.5 & 39.7 & 46.0 \\
\hline $\mathrm{Fe}$ & $<1.05$ & $<1.05$ & $<1.05$ & $<1.23$ & 1.6 & 1.47 & 5.23 \\
\hline $\mathrm{K}$ & 223 & 364 & 515 & 232 & 290 & 309 & 348 \\
\hline $\mathrm{Mg}$ & 0.285 & $<0.12$ & $<0.12$ & $<0.1$ & $<0.1$ & $<0.1$ & $<0.15$ \\
\hline $\mathrm{Mo}$ & $<11.2$ & $<5.75$ & $<5.75$ & $<9.83$ & $<5.99$ & $<5.99$ & 8.02 \\
\hline $\mathrm{Na}$ & 93200 & 120000 & 131000 & 113000 & 127000 & 128000 & 148000 \\
\hline $\mathrm{P}$ & 102 & 135 & 149 & 121 & 149 & 156 & 176 \\
\hline $\mathrm{S}$ & 1160 & 1860 & 2060 & 1820 & 2160 & 2330 & 2645 \\
\hline $\mathrm{Ti}$ & 6.15 & 6.90 & 7.75 & 5.2 & 5.09 & 1.87 & $<0.38$ \\
\hline $\mathrm{Zn}$ & 5.43 & 7.96 & 4.94 & 3.55 & 6.24 & 10.8 & 5.09 \\
\hline
\end{tabular}

The analytical uncertainty for the ICPES samples is $10 \%$.

Table 4. ICPES Results for the SEHT Samples (mg/L)

\begin{tabular}{|c|c|c|c|c|c|}
\hline Analyte & $\begin{array}{c}\text { MCU- } \\
12-305\end{array}$ & $\begin{array}{c}\text { MCU- } \\
12-408\end{array}$ & $\begin{array}{c}\text { MCU- } \\
12-501\end{array}$ & $\begin{array}{c}\text { MCU- } \\
12-539\end{array}$ & $\begin{array}{c}\text { MCU- } \\
13-08\end{array}$ \\
\hline $\mathrm{Al}$ & 5.07 & 4.29 & 3.93 & 4.65 & 25.3 \\
\hline $\mathrm{B}$ & 1.55 & $<0.601$ & $<0.579$ & $<0.597$ & $<0.350$ \\
\hline $\mathrm{Ba}$ & $<0.330$ & 0.227 & 0.186 & 0.225 & 0.332 \\
\hline $\mathrm{Ca}$ & 7.80 & 6.47 & 5.61 & 6.24 & 6.38 \\
\hline $\mathrm{Cr}$ & $<0.648$ & $<0.405$ & $<0.649$ & $<0.669$ & 0.405 \\
\hline $\mathrm{Fe}$ & 15.5 & 12.3 & 10.5 & 13.5 & 14.5 \\
\hline $\mathrm{K}$ & $<10.2$ & $<7.19$ & 8.15 & 7.62 & $<6.94$ \\
\hline $\mathrm{Mg}$ & 0.663 & 0.598 & 0.442 & 0.462 & 1.05 \\
\hline $\mathrm{Mo}$ & $<3.36$ & $<2.97$ & $<2.86$ & $<2.95$ & $<1.75$ \\
\hline $\mathrm{Na}$ & 19.3 & 66.5 & 69.5 & 69.3 & 79.0 \\
\hline $\mathrm{P}$ & $<6.87$ & $<5.05$ & $<14.0$ & $<14.4$ & $<4.87$ \\
\hline $\mathrm{S}$ & $<180$ & $<181$ & $<175$ & $<180$ & $<175$ \\
\hline $\mathrm{Ti}$ & $<0.120$ & $<0.175$ & 0.189 & $<0.126$ & $<0.169$ \\
\hline $\mathrm{Zn}$ & 17.3 & 14.1 & 12.6 & 13.8 & 13.7 \\
\hline
\end{tabular}

The analytical uncertainty for the ICPES samples is $10 \%$. 
The titanium results in the DSSHT samples are notable. In all cases, we have greater than detectable levels of $\mathrm{Ti}$ in the samples, where there is less-than detectable amounts in the feed material. This is important, as the only possible source of Ti is from the MST used at ARP. In fact, SRNL has found evidence of Ti-containing solids in the DSSHT coalescer and pre-filters. Testing in progress at SRNL has shown that Ti leaching from MST increases at higher free hydroxide concentration in the waste solution; this is suspected as a contributor to the Ti component in the MCU samples. ${ }^{5}$ The drop in Ti results for the final DSSHT sample may be indicative of the reduced MST usage at ARP. While the MST strike amounts were reduced in November, the effects of the reduction may of taken some time to be observed in the DSSHT results.

The SEHT samples follow the general trends observed for the previous sample results. ${ }^{2}$ The high Al result for the last sample (MCU-13-08) is higher than historical values. However, initial results from Salt Batch 6 samples are within historical values. This is a good indication that the bulk chemistry has minimally changed, and also suggests that the aqueous carryover from the feed material into the solvent, and then back to the SE is not varying too greatly.

\subsection{Conclusions}

The results from the current microbatch samples are similar to that from comparable samples in Macrobatch 4.

From a bulk chemical point of view, the ICPES results do not vary considerably between previous results and this macrobatch.

Finally, the titanium results in the DSSHT samples continue to indicate the presence of $\mathrm{Ti}$, when the feed material does not have detectable levels. This most likely indicates that leaching of Ti from MST has increased in ARP at the higher free hydroxide concentrations in the current feed. The last DSSHT sample, with the reduced Ti result, may be a reflection of the reduction in MST at ARP.

SRNL recommends that in the future, when samples are delivered, the customer should make a note of how many MST additions have been made before the sample was pulled. This will enable SRNL to more accurately understand the effects of MST on the Pu and Sr results. 


\subsection{References}

${ }^{1}$ M. W. Geeting, “Interim Salt Disposition Project (ISDP) Sample Plan”, U-ESR-H-00068, Revision 5, April 28, 2009.

${ }^{2}$ Peters, T. B., Fink, S. D., “Results of Routine Strip Effluent Hold Tank, Decontaminated Salt Solution Hold Tank, and Caustic Wash Tank Samples from Modular Caustic-Side Solvent Extraction Unit during Macrobatch 4 Operations” SRNL-STI-2012-00430, October 2012.

${ }^{3}$ T. B. Peters, S. D. Fink, “Results from ISDP4 Tank 49H Confirmatory Samples”, SRNL-STI-2012-00024, February 2012.

${ }^{4}$ T. B. Peters, S. D. Fink, "Sample Results from the Integrated Salt Disposition Program Macrobatch 5 Tank 21H Qualification Samples”, SRNL-STI-2012-00076, March 2012.

${ }^{5}$ K. M. L. Talyor-Pashow, F. F. Fondeur, S. D. Fink, "Leaching of Titanium from Monosodium Titanate (MST) and Modified MST (mMST)”, SRNL-STI-2012-00237, August 2012. 